\title{
Does Outsourcing Result in the Outsourcing of Technological Competencies? An Empirical Analysis of the Effect of Vertical Specialization on the Technological Competence Base of Firms
}

Over the past two decades multinational firms from high-technology industries have increasingly relied on outsourcing of production to external suppliers. We present a theoretical framework that stems from the resource-based view of the firm (RBV) and develop hypotheses claiming that outsourcing of production will not result in the outsourcing of technological competencies. In other words, vertical specialization will not result in the reduction of the breadth and depth of the technological competence level of firms, especially in high-technology industries. We test our hypothesis with a sample of 50 firms which we selected from the population of the world's top R\&Dperforming firms, measured by R\&D spending. The period of investigation covers 20 years from 1983-2002. Our results indicate that over this 20 years period the technological knowledge base of the sample firms has not been affected by the ongoing outsourcing activities. The empirical observation gives rise to the 'a priori statement' that the knowledge-boundaries of the firms have been decoupled from production activities: In our sample of firms from high-technology industries outsourcing has not coincided with the outsourcing of technological competencies.

Key words: outsourcing, technological competencies, internationalization, product diversification, resourced-based view of the firm

* Prof. Dr. Michael Stephan, University of Marburg, Department of Technology and Innovation Management, Am Plan 1, 35037 Marburg, Germany.

E-mail: michael.stephan@wiwi.uni-marburg.de.

** Article received: July 7, 2009

Revised version accepted after double blind review: April 15, 2010. 


\section{Introduction}

Since the Industrial Revolution, firms in almost all industries have increasingly become specialized and only rarely command all the necessary production activities of their products' value chains in-house (Bruisoni et al. 2001). Especially when firms produce complex, technology-intensive products they usually outsource parts of the production and even parts of the development processes to external suppliers. Many firms are doing business in industries in which competition is largely driven by innovation and in which technological competencies are at the heart of any competitive advantage. Over the past two decades, the majority of these firms have outsourced an increasing part of production to external suppliers (Bengtsson/Dabhilkar 2008; Gerybadze/Stephan 2007). Using key-words such as outsourcing, vertical specialization, lean production, refocusing on core skills and competencies, or deconstruction of value chains, many theoretical papers and a few empirical studies have investigated the outsourcing phenomenon in the context of strategic management and supply chain management research as well as in industrial economics.

The increasing division of labor between independent firms alongside their product value chains in the course of outsourcing strategies has also been discussed under the term 'vertical specialization' (Macher/Mowery 2004: 318-19):

"Vertical specialization is also termed vertical disintegration, and often is associated with the entry of specialist firms into distinctive segments of the vertical value chain. Vertical specialization [...] may be defined as a shift from vertically integrated control of product value chains by the firm to a structure characterized by market-based coordination [...] among separate firms."

According to this definition, vertical specialization depicts the phenomenon which occurs when the various activities within an industry's value chain are under the control of various separate firms that have specialized on a selected range of activities. The process of vertical specialization therefore describes the change from the status of vertical integration in which single firms control and command large parts of the valuechain activities in-house to a less integrated and less hierarchically controlled product value chain. Such a process of vertical specialization is a synonym for the outsourcing of production (and development activities) to external suppliers. From a firm's perspective outsourcing leads to a reduction in the value-add quota (net value added as a percentage of sales).

From an empirical perspective, the trend of outsourcing has been observed across many industries. Especially in branches with complex products, such as the automotive, telecommunication, engineering and computer industries, outsourcing has been found to be a prominent trend across the OECD countries (DTI 2004; DBIS 2009).

From a theoretical perspective, there are numerous explanations of why firms engage in outsourcing. Traditionally, neoclassical explanations with roots in cost and (lean) production theory have been put forward to solidify arguments pro outsourcing. In this view outsourcing may lead to a reduction in costs and an increase in flexibility. More differentiated arguments for the explanation of outsourcing strategies have been 
developed in the light of the resource-based view of the firm and by transaction cost theory (Bruisoni et al. 2001).

Although vertical specialization has been well analyzed in management research both from theoretical and empirical perspectives (the latter primarily on a case study level), the effect of outsourcing on the firms' technological competencies has only been investigated by a few studies and purely on a theoretical level (Stigler 1951; Jensen/Meckling 1976; Chandler 1990; Chesbrough/Teece 1996; Sanchez/Mahoney 1996; Baldwin/Clark 2000; Langlois 2000, 2003; Leiblein et al. 2002; Macher 2003; Rothaermel et al. 2006). This lack of insight is an obvious gap in management research: A critical determinant of sustainable competitive advantages of firms in high technology industries is their capability to generate product and process innovations. In turn, their ability to innovate is largely determined by the underlying technological competence base of the firms. We will argue that firms, which operate in innovationdriven industries, do not tend to outsource technological competencies alongside the outsourcing of production. Instead firms retain those technological competencies inhouse, which underlie the components that have been outsourced to suppliers.

Our arguments for keeping technological competencies in-house are developed out of the resource-based theory of the firm: In order to stay innovative in the long run, firms must also retain technological competencies in those areas of activities that have been outsourced. We test our hypotheses empirically with a sample of 50 multinational and top R\&D-performing firms (by R\&D spending). The empirical investigation comprises a longitudinal study covering a 20-year period, from 1983 to 2002, which provides the basis for testing the mid and long term effects of outsourcing.

Section 2 of the article is devoted to the generation of hypotheses that underpin our theoretical model. Section 3 presents the methodology used in the empirical investigation. More precisely, the section on methodology portrays and discusses the way we operationalize the dependent variable (the technological competence base of firms) and the independent variable (change in the value-add quota) as well as other control variables. Finally, we present and discuss the results of the empirical study in section 4 and 5 , including remarks and implications for future research.

\section{Theoretical framework: Outsourcing and innovativeness in the light of the resource- and competence-based view of the firm}

\subsection{Outsourcing and technological competitiveness of firms}

Does the outsourcing of production and other related value adding activities result in the outsourcing of the corresponding technological competencies? This is the core research question that we try to answer in the present study. More specifically, we investigate the impact of outsourcing of production and other value adding activities to external suppliers on the breadth and depth of the technological competence base of firms. Following Prencipe (2000: 898), the breadth and depth of a firm's technological competence base is defined:

"... as the number of distinct technological fields that are maintained in-house."

According to firm and industry level case studies in technology-intensive environments, the amount of (technological) knowledge of firms greatly exceeds the range of 
their product-related activities. This is primarily due to the complex nature of these products (Bruisoni/Prencipe 2001; Gambardella/Torrisi 1998; Cesaroni 2004; Prencipe 1997; Stephan 2003; Stephan/Pfaffmann/Sanchez 2008; van Tunzelmann 1998).

Within neoclassical explanations, which define firm boundaries from a rather monolithic view, there is a lack of rationale as to why firms outsource production and nonetheless invest in the sophistication and expansion of the corresponding technological resources and competencies. In contrast, the transaction cost theory offers a clear explanation of why firms should keep in-house technological competencies when they outsource parts of their production to external suppliers: Keeping competencies in-house protects against the threat of opportunistic behavior by suppliers, especially when the outsourced activities are characterized by asset specificity. Another explanation for maintaining technological competencies in-house is offered by the resourcebased view (RBV) of the firm. The RBV arguments complement the transaction cost theory arguments, though, without referring to the underlying assumptions of bounded rationality and opportunistic behavior.

In the RBV, the basic units of analysis are the resources or the resource combinations (bundles of resources) which a firm commands and which are firm-specific. The RBV distinguishes between different kinds and categories of resources. Within the different strands of RBV research there are many different resource typologies in use, a commonly accepted nomenclature has not evolved so far. Nevertheless, the least common denominator is the basic distinction between 'resources' and 'competencies'. The term 'resource' refers to the resource endowment of the firm and includes all kinds of material as well as immaterial resources, including technological knowledge, that are available to the firm. In contrast, 'competencies' are action-based resources that refer to the capability of firms to unfold the potential of their resource endowments and to make use of these resources in competition (Freiling 2004).

Within the plethora of RBV research there are two perspectives which offer explicit arguments of why firms should keep in-house technological competencies and resources although they engage in outsourcing: (1) the 'absorptive capacity' view and (2) the 'dynamic capabilities' concept. The concept of 'absorptive capacity' was introduced by Cohen and Levinthal in 1990. According to them, absorptive capacity denominates the firm's ability to detect and explore valuable (technological) knowledge outside its boundaries, which resides with suppliers, customers, competitors etc., and to integrate these external pieces of knowledge with its own resources to innovate successfully. According to Cohen and Levinthal such an absorptive capacity for technological knowledge can only be developed and nourished by continuous in-house R\&D activities that go beyond the traditional knowledge platform of the firm.

This argument gains particularly in importance for firms that develop and produce complex products. The various technologies that are applied and put into use in complex systemic products are usually related as they functionally complement each other (Bruisoni et al. 2001; Ethiraj/Puranam 2004; Metcalfe 1998). If the relatedness of the individual technologies is characterized by reciprocities and interdependencies, then firms must build up and maintain corresponding background knowledge also in areas that have been outsourced to external suppliers. Such background knowledge in supplier domains is required, in order to correctly identify, analyze, integrate and 
match the technologies of suppliers to one's own. The lack of such background knowledge in collaborative product development projects may lead to additional costs (due to delays and necessities for redesigns) which offset the costs of maintaining such knowledge (Stephan et al. 2008). The accumulation of technological knowledge and competencies in supplier domains reinforces the absorptive capacity of the firm also in the way that a shared language and common innovation culture is created, which in turn facilitate the coordination between the firm and its suppliers.

The concept of 'dynamic capabilities' offers a more dynamic view and explanation for keeping in-house technological knowledge when outsourcing parts of production. The 'dynamic capabilities' concept was originally introduced by Pettigrew and Whipp (1993), and reworked and expanded by Teece, Pisano and Shuen (1997), Eisenhardt and Martin (2000), and Zollo and Winter (2002). 'Dynamic capabilities' describe the firm's ability to permanently renew and replenish its resources and competencies in response to constantly changing environmental and market conditions. More specifically, Teece, Pisano and Shuen (1997: 516) define dynamic capabilities

“....as the firm's ability to integrate, build, and reconfigure internal and external competences to address rapidly changing environments."

Due to outsourcing firms are integrated into development and production partnerships with external suppliers. Consequently, a firm's ability to address rapidly changing environments should also include the changes and adjustments required on the part of the external suppliers. Therefore, the ability to initiate, coordinate and command the technological change in the external network requires that the firm possesses technological competencies beyond its core knowledge base in the domains of its suppliers. Even more, the necessity to cultivate technological competencies in supplier domains becomes imperative when there are imbalances in the developments of the various supplier technologies (Bruisoni et al. 2001: 608). Within complex product systems it is likely that uneven technological developments will occur (so called 'reverse salients'): Technological advances in one component may require adjustments and follow-up developments in the performance of other component technologies to make the product fully functional. If the responsibility for the individual component technologies is scattered across various firms, then a 'systems integrator' is required. The firm that takes over the system integrator's role must develop and command technological knowledge in the domains of its suppliers, simply to assure its innovative capabilities with regard to the whole product system (Macher/Mowery 2004).

The 'absorptive capacity' view and the 'dynamic capabilities' concept offer complementary explanations as to why outsourcing will not result in the outsourcing of technological competencies: The arguments of the 'absorptive capacity' view primarily refer to the firm's current competitive position and to its existing technology and product portfolio. In contrast, the dynamic capabilities perspective is focused on sustaining the long-term competitive advantage of the firm including technological developments for future products. However, both perspectives agree in that the greater the division of labor in the value-chain and the bigger the interdependences between individual product components are, the larger the incentives for firms will be to invest in technological competencies outside of their core domains. The development of technological competencies outside of core domains acts as a (dynamic) interface to 
access external sources of technologies. In contrast to the arguments delivered by the transaction cost theory approach, the RBV offers explanations beyond the threat of opportunistic behavior on the suppliers' side. The partnerships between a firm and its external suppliers are characterized by long-term and cooperative relationships that are largely built on trust (Saxenian 1994; Dyer/Singh 1998).

The line of argumentation developed out of the RBV framework, namely based on the 'absorptive capacity' view and the 'dynamic capabilities' concept, leads us to our first hypothesis, that in technology-intensive industries outsourcing (vertical specialization) will not lead to a similar reduction in the breadth and depth of the technological competence level: Firms will keep critical supplier technologies in-house:

Hypothesis 1: Vertical specialization has a negative but moderated effect on the breadth of the technological competence base of firms.

\subsection{Determinants of the technological competence base: Beyond outsourcing}

In addition to vertical integration, the breadth and depth of the technological competence-base is affected by other strategic decisions and moves that firms undertake. A prime determinant is growth and diversification into new markets that has a positive effect on the technological competence base (Buehner 1991; Granstrand/Oskarsson 1994; Stephan 2003). In the context of diversification strategies, two motives for the enlargement of a firm's technology base must be distinguished: (1) exploration of new product markets and (2) exploration of new geographical markets. Subsequently, we will discuss the influence of product expansion and internationalization on the technology base of firms in more detail. We develop two additional hypotheses to complement our model on outsourcing and the technological competence base.

\section{Impact of the product portfolio on the technology base of firms}

The breadth of the technology base of firms is greatly influenced by the breadth and characteristics of a firm's product portfolio (Stephan 2003). If firms plan to diversify into new product markets, then this requires the preceding enlargement of the technology base into areas which are inherent to and associated with the new product. This basic motif fully corresponds to the motif of technological diversification outlined by Penrose (1959). The expansion of technological activities is stimulated by the credo that technological innovation is a prime source for new business opportunities and growth. Innovation may be either triggered by scientific progress (technology push) or by the localization of new market needs (market pull) (Granstrand/Sjölander 1990). Firms will be likely to invest in the exploration and accumulation of new technologies (via in-house $\mathrm{R} \& \mathrm{D}$, collaborations, licensing etc.) when they have a vision about the usefulness of the new technology and its potentials for commercialization. The more precise and articulated the business vision is, the bigger the likelihood of firms to tap into technologies via in-house R\&D (Christensen 1998). Accordingly, tapping into new products and exploring new business opportunities is a major stimulus for the expansion of the technological competence base of firms.

While product diversification has proved to be a popular strategy for the growth of firms until the late 1980's, many studies have observed that since the early 1990's, firms rather tend to refocus their product portfolio than to enlarge it (Markides/Wil- 
liamson 1994; Stephan 2003). Spin-offs of peripheral businesses and divestments of unrelated product fields lead, correspondingly, to the divestment of the underlying technologies and thus to a decrease of the technological competence base of firms. In contrast to outsourcing and vertical specialization such a spin-off entails the entire withdrawal from a product area including all corresponding activities in the value chain. Especially those product areas will be considered to be non-core and peripheral, whose technology base lack economies of scope with the core products. Under such circumstances the spin-off of peripheral products will go hand in hand with the spinoff of the underlying technologies (Stephan 2003).

The second hypothesis in our model predicts a positive causality between the degree of product diversity and the breadth of a firm's technology base.

Hypothesis 2: Product diversification has a positive impact on the breadth of the technological competence base of firms.

\section{Impact of internationalization strategies on the technology base of firms}

Over the past two decades, most technology-intensive firms have shifted the focus of their growth strategies away from product diversification to geographical diversification, i. e. they have expanded their business activities to foreign markets (UNCTAD $2008,1998)$. The exploration of new geographical markets usually requires the adaptation of the products and services to the local market conditions abroad. In most cases firms will not be able to simply 'transplant' their product offerings without any changes to the foreign markets. The need for local adaptation may arise out of different customer preferences and consumer tastes, or varying regulatory frameworks in the local industry. In many cases the need for local adaptation calls for changes in the product design or for component changes. Such design and component changes in turn may call for technology changes and require firms to tap into new technologies and therefore to enlarge the technological competence base.

However, the expansion of a firm's technology base due to geographical expansion will be limited. Firms tend to focus international expansion activities on their core product lines (Gerybadze/Stephan 2007). Such core products tend to represent those businesses in which the firms can (in principle) compete successfully in the global market place, or at least in the triad regions (Rugman 2008). By definition, the internationalization of such core products with an inherent global business potential will require only minor changes and adaptations for foreign market introduction. The core design and basic component technologies will remain unchanged. Furthermore, firms will target internationalization steps primarily to those markets that share many similarities with their home markets. Internationalization steps are often confined to markets with similar cultural backgrounds and customer segments, homogenous legal frameworks etc. Therefore, the pressures for firms to expand the technology base due to the adoption of an international growth strategy will be limited. Despite this limitation, we claim a positive causality between the degree of internationalization and the breadth of a firm's technology base. However, the positive relationship will not be as strong as the one predicted by hypothesis 2 on the impact of product diversification. 
Hypothesis 3: The geographical diversification of sales has a positive though moderate impact on the breadth of the technological competence base of firms.

\section{Role of product complexity on the technology base of firms}

In addition to product diversification and internationalization, changes in the technological complexity of the product portfolio will have an impact on a firm's technology base. In most technology-intensive industries, products and the underlying production processes are characterized by technological complexity. Complexity implicates that firms must command and coordinate a multitude of different product and process technologies, which in dynamic environments are subject to constant changes. To stay competitive in rapidly changing technological environments, firms are constantly forced to expand their technology base to encompass new complimentary or even radically new technologies. Consequently, in such dynamic environments there is an inherent pressure for firms to invest in the enlargement of their technological competence portfolio, even if they do not tap into new product or geographical markets (Cantwell/Piscitello 1999; Jolly 1997).

The necessity to invest in new technologies in complex product environments is reinforced by the convergence of previously independent and unrelated technologies (Fai/Cantwell 1999). Technological convergence implies the emergence of functional (and reciprocal) interdependencies between previously independent technologies and even the fusion of technology areas. Such a crosslinking of knowledge domains promotes the joint use and combination of technologies in one single product, to add new functionalities and to improve the performance (Granstrand/Oskarsson 1994; Carlsson/Stankiewicz 1991). ${ }^{1}$ Convergence increases the complexity of products and creates more stimuli for firms to broaden their technological competence base.

Hypothesis 4 in our model specifies the rising complexity in the firm's existing product portfolio. To stay competitive firms are constantly forced to expand their technology base to encompass new complimentary or even radically new technologies, especially when they are confronted with technological convergence.

Hypothesis 4: The complexity of products has a mediating and positive impact on the breadth of the technology base of firms which rely on outsourcing.

\section{Notes on methodology}

\subsection{Sample selection and firm characteristics}

Our empirical study covers a time period of 20 years ranging from 1983 to 2002 and consists of a sample of 50 multinational corporations that have been selected from the population of the top 200 R\&D-performing firms, measured by their R\&D spending in the fiscal year 2002. All sample firms are key players in the global innovation system. Altogether, the 50 sample firms invested 152 billion Euros in R\&D in 2002. In

Advances in (micro-)electronics and new materials have promoted the convergence of previously unrelated technology areas and created new potentials for combined technology usage. 
sum, the consolidated R\&D budget equals 33 percent of all privately financed $R \& D$ expenditures in the OECD countries (business expenditures on R\&D, BERD).

For the sample composition from the population of the top $200 \mathrm{R} \& \mathrm{D}$ performing firms, we used two selection criteria: (a) structural and (b) longitudinal criteria. Category (a) refers to the type and characteristics of the business activities of the firms. All of our sample firms have a diversified product portfolio, i. e. they are doing business in a least three ISIC-Classes (International Standard Industry Classification of all Economic Activities), and all have internationalized their sales activities, i. e. they are MNCs and do business in more than one country. The sample is exclusively composed of firms which have concentrated their business activities in the manufacturing sector. We have excluded firms with a major stake in the aerospace and defense business, due to the strong governmental influence on $R \& D$ and the development of new technologies. Leaving aside aerospace and defense, our sample firms can be clustered to six industry groups: Automotive (9 firms); chemicals / materials (11); pharmacenticals (9); mechanical / industrial engineering (4); electrical engineering / electronics (9); telecommunications / data processing (8).

Category (b) of our selection criteria centers on longitudinal aspects. The investigation of the outsourcing behavior covers a period of 20 years ranging from 1983 to 2002. It is thus important that the sample firms were operating autonomously as independent and non-affiliated entities within this period. Furthermore, we emphasized that the structural selection criteria of category (a) were already being met at the beginning of the investigation period. Taking into account these knock-out criteria our sample represents a complete survey of the population of big R\&D performing firms.

Without exception, all of the sample firms have their headquarters in triad countries. Firms from Europe are the most represented with a total of 24 firms. Another 15 firms are headquartered in the U. S. / Canada and 11 are based in Japan.

\subsection{Operationalization and measurement of technological competencies}

The technological competence base of firms is the dependent variable in our model. Unfortunately, a direct measure for technological competencies of firms is not available. In literature, several proxies are discussed and suggested for use to measure technological competencies (Cantwell/Piscitello 1999; Cantwell/Piscitello 1997; Narin et al. 1984; Pavitt 1988). In summary, there is a broad consensus to use firms' patent filings as the most valid (though not perfect) proxy for technological competencies (Gavetti 1994; Pavitt 1988; Stephan 2003). We follow this approach and use patent applications of the firms at the European Patent Office (EPO) to measure the breadth of the technological competence base (and its change over time).

Patent documents contain detailed information about the individual technology areas in which the firms have accumulated new or have substantially improved and expanded existing knowledge. Therefore, the analysis of the patterns of patent filings across different technology areas over time allows for detailed insights into the spectrum of the technological activities of the firms, decoupled from their products (Andersen/Cantwell 1999; Stuart/Podolny 1996). Furthermore, the use of the firms' patent filings at the EPO allows for minimizing the home country bias when comparing 
the technological activities of the sample firms headquartered across the U.S./Canada, Japan and Europe (Schmoch 1999).

The quantification and comparison of the breadth of the technological competence base of the firms requires an appropriate classification system to bring order into the 'universe' of technologies. An appropriate and universally accepted taxonomy is the International Patent Classification (IPC) that offers a system to classify and organize patents into different technology areas. The IPC is a hierarchical classification system for patentable technological knowledge and purely based on technological and functional principles. It is thus independent of products and application areas.

For each firm we have compiled technology profiles based on the number of the firms' patent applications across individual IPC classes. In order to avoid random or cyclical fluctuations when preparing the technology profiles over the 20 years period we have summarized the patent filings for periods of five years. We subdivided our overall period of investigation into four intervals and prepared technological competence profiles for the sub-periods 1983-1987, 1988-1992, 1993-1997 and 1998-2002.

In addition to assess the spread of patent filings across all IPC classes it was of relevance to assess the degree of relatedness between the individual technology areas in which the firms were active. For this reason we applied the OST/INPI/ISI classification system. The OST/INPI/ISI classification system is a widely acknowledged and empirically tested taxonomy to summarize and aggregate IPC classes according to the relatedness of the underlying technological knowledge. The OST/INPI/ISI classification system reduces and clusters the IPC system into 30 homogenous technology areas, and, on a higher aggregation level, into five broader technology fields (Gavetti 1994). Following this classification system we assigned the patent filings of each firm to 30 technology areas and, in turn, to five broader technology fields.

The breadth of the technological competence base of firms, i.e. the degree of technological diversification, was quantified and calculated with a revealed technological advantage-measure (RTA). The RTA measure for the degree of technological diversification of firm $x$ is based on the consideration that the breadth of the technological competence base is inversely related to the extent of the concentration of the firm's technological specialization in individual technology areas (Cantwell/Piscitello 1999, 1997; Fai/Cantwell 1999; Patel/Pavitt 1997). The firm's specialization can be measured by an index of its revealed technological advantage (RTA) which for each particular area of technological activity is defined by the firm's share in that area of EPO patents granted to all firms, relative to the firm's overall share of all EPO patents. Specifically, denoting as $P_{i x}$ the number of EPO patents granted in technology area $i$ to firm $x$, then the $R T A_{i x}$ index is defined as follows:

$$
R T A_{i x}=\left(\frac{P_{i x} / P_{\text {itotal }}}{P_{x} / P_{\text {total }}}\right)
$$

The index varies around unity, such that values greater than one suggest that a firm is comparatively advantaged in the area of activity relative to other firms. Values less than one are indicative of a position of comparative disadvantage. 
Importantly, the use of the RTA-based diversification index allows us to control for inter-sectoral and inter-firm differences in the propensity to patent. In general, the RTA index immunizes against differences in the absolute number of patent filings, due to different firm sizes or patent propensities. A higher number of patent filings naturally leads to a broader dispersion of the patents across technology areas. This effect must be interpreted as noise simply because of a higher patenting scale (Cantwell/Piscitello 1997, 1999). The RTA index helps to minimize this noise.

The proxy for the degree of technological specialization $R T A S_{x}$ of the firm $x$ is measured by the coefficient of variation of the RTA index across all of the relevant technology areas $i$ of the firm in each sub-period considered:

$$
R T A S_{x}=\frac{\sigma_{R T A_{x}}}{\mu_{R T A_{x}}}=\frac{\sqrt{\frac{1}{N} \sum_{i=1}^{N}\left(R T A_{i x}-\overline{R T A}_{x}\right)^{2}}}{\overline{R T A}_{x}}
$$

Small values of the $R T A S_{x}$ measure indicate that there is only little concentration and specialization in the firm's technological competence base. Obviously, the technological activities are distributed equally across many relevant technology areas. In contrast, high values indicate a stronger technological specialization of the firm. To quantify the degree of technological diversification $T D_{x}$ of the firm $x$ in each sub-period considered, we used the reciprocal of the $R T A S_{x}$ (inverse of the coefficient of variation) as a proxy. In particular:

$$
T D_{x}=\left(\frac{1}{R T A S_{x}}\right)=\left(\frac{\mu_{R T A_{x}}}{\sigma_{R T A_{x}}}\right)
$$

\subsection{Operationalization and measurement of the explanatory variables}

Our model of the effects of vertical specialization on the technological competence base of firms incorporates four hypotheses. All four hypotheses specify causal relationships between an explanatory variable and the dependent variable - the breadth of the technological competence base of the firms. In contrast to the dependent variable, the explanatory variables in the model (vertical specialization, product diversification, internationalization and product complexity) can be observed more or less directly. In most cases state-of-the-art procedures are at hand for measurement. In the subsequent sections we discuss the operationalization and measurement approaches for each variable separately. All approaches comply with the approved procedures in management research and are intensively discussed in literature.

\section{Quantifying outsourcing: Degree of vertical specialization}

In our empirical investigation we consider the 'degree of vertical specialization' to be a real economic value and quantitative figure: On the micro level of the individual firm the most appropriate quantitative parameter to assess vertical specialization is the value-add quota (or real net output ratio) of the firm, which is calculated as the net value added as a percentage of sales (or net production). From the firm's perspective outsourcing (insourcing) leads then to a reduction (increase) in the value-add quota. 
The value-add quota $\left(V A_{x}\right)$ is calculated by using financial data from the profit and loss statement of firm $x$. The value-add quota $\left(V A_{x}\right)$ refers to the firm's operations during a specific fiscal period (in the following we use the fiscal year).

Basically, there are two approaches to calculate $V A_{x}$ on the basis of the firm's income statement: The 'value creation'-calculation uses the net production value (revenues plus/minus inventory changes and capitalized services) as a starting point. The value-add is calculated by subtracting all accounts payable from the net production value, i.e. the market value of all products and services sourced from external partners (Haller 1997; Weber 1994). The 'value distribution'-calculation uses, as a starting point, the income of all stakeholders that have contributed to the creation of the value-add and benefited from its distribution. The value-add is then calculated by adding the value of income of the stakeholders: personnel expenses (wages/salaries plus social security and pension costs), interest payments on debt, income taxes and distributed earnings (dividends) to the retained earnings. In principle, both backward and forward calculation should lead to the same result. Finally, the value-add quota is calculated by the value-add as a percentage of net production (Haller 1997; Stephan 2003).

\section{Quantifying the breadth of the product portfolio: Degree of product diversification}

Product diversification is defined as the expansion of the firm's output, in terms of goods and services, into new product markets (Markides/Williamson 1994; Rumelt 1974). To distinguish product diversification from vertical integration it is sometimes also referred to as horizontal diversification. The degree of product diversification is measured by the sales split of a firm across different product markets and industries. Using a standard classification approach we apply the "International Standard Industrial Classification of all Economic Activities, Third Revision (ISIC Rev.3.1)" for classifying the firms' revenues. We use the classification system on a two- to three-digit level and distinguish between a total of 68 product classes. The revenues of the sample firms are split up and assigned to the $\mathrm{k}=68$ different product classes. The information about the revenue distribution of the firms across these 68 classes was taken from the Compustat database and complemented by information taken from company documents (annual reports, 10Ks, 20Fs).

We use the Jacquemin-Berry index, known as the entropy index, to quantify product diversification on a metric scale. This entropy index has been the most used in economic and management research. ${ }^{2}$ As we are only interested in the total degree of product diversification and not in the diversification strategies of the firms (related versus unrelated diversification), we simply apply a one step calculation: For each of the sample firms the degree of product diversification $\left(P D_{x}\right)$ is computed as follows (let $P_{k}$ be the share of the $k$ th industry segment in the total sales of the firm):

$$
P D_{x}=\sum_{k=1}^{68} P_{k} \ln \left(\frac{1}{P_{k}}\right)
$$

2 The index has traditionally been used by economists, e. g. Jacquemin/Berry (1979), and was imported into strategic management research by Palepu (1985). See Markides (1996). 
The entropy measure takes into consideration two elements of diversification: the number of industry segments in which the firm operates and the relative importance of each of these product segments in the total sales of the firm.

\section{Quantifying internationalization: Degree of geographical diversification}

The discussion of how to measure and quantify the degree of internationalization of firms has a long standing tradition in international management research. Empirical studies frequently use foreign direct investment (FDI) activities of firms as an indicator to assess the degree of internationalization (Stephan/Pfaffmann 2001). However, the FDI indicator primarily aims at international production activities. In our model, we have defined internationalization in hypothesis 3 as the expansion of a firm's sales to foreign markets. Undoubtedly, it is difficult to completely separate the phenomenon of internationalizing sales from internationalizing production. Especially in large foreign markets with a considerable need for local adaption of the product offerings, firms also tend invest in local production activities to back and catalyze their sales. As FDI activities in these cases play a complementary and supportive role, we focus on the foreign sales activities in our approach to measure internationalization.

In order to determine the degree of internationalization of the sample firms, we take a look at the distribution of sales across foreign markets. Similar to product diversification we use a geographical diversification measure. The international diversification of the sales is assessed by the sales split across the five world regions (Asia and the Pacific, North America, Latin and South America, Europe, Africa and the Middle East). Furthermore, the home country of each sample firm is counted as a sixth market (Hitt el. 1997). Each of these six market regions $(m=1 \ldots \mathrm{R} ; \mathrm{R} \leq 6)$ can be interpreted as a relatively homogenous market place, concerning the internal cultural, political and demographic conditions, that differs significantly from the other regions. For each firm $x$ the degree of geographical diversification $\left(G D_{x}\right)$ is computed as follows (let $G_{m}$ be the share of the $m$ th world market in the total sales of the firm):

$$
G D_{x}=\sum_{m=1}^{6} G_{m} \ln \left(\frac{1}{G_{m}}\right)
$$

In contrast to simple FTO-sales measures, the GDx entropy measure controls for small and big home country effects and distinguishes significantly different markets that may call for local adaptation.

\section{Determining complexity: Technological complexity of the product portfolio}

Unlike the other variables in our model, technological complexity of a firm's products is not related to the whole corporation but only to single products within the firm's product portfolio. This focus of analysis on individual products or product groups makes it difficult to determine 'technological complexity' for the whole firm in aggregate and thus creates a challenge to quantify the degree of complexity (by which the firm is confronted) on a metric scale (Granstrand/Oskarsson 1994).

Instead of quantifying the degree of technological complexity for each sample firm we use industry dummies as proxies for complexity. The use of industry dummies is based on two assumptions: (1) Sample firms that operate in the same industry will 
have similar product offerings with regard to the underlying technology base. (2) Similar product offerings (from a technological perspective) are characterized by similar levels of technological complexity. Consequently, firms from within the same industry must manage similar degrees of technological complexity in their product portfolio and are confronted with comparable pressures for technological change. We thus determine the technological complexity of the products of our sample firms by using six dummy-variables (categorical variable-type) which correspond to the six industry clusters in the sample: $A U$ (automotive); $C H$ (chemicals/materials); $P H$ (pharmaceuticals); $M B$ (mechanical-/industrial engineering); EL (electrical engineering/electronics); IT (telecommunications / data processing).

\subsection{Model specification}

The empirical study can be divided into two parts. In the first step, we conduct a descriptive empirical analysis of the development of the breadth of the technological competence base of the firms (degree of technological diversification, $T D_{x}$ ) as well as of the independent variables value-add quota $\left(V A_{x}\right)$, degree of product diversification $\left(P D_{x}\right)$ and geographical diversification $\left(G D_{x}\right)$. The descriptive analysis provides an overview of the trends over the 20-year period from 1983 to 2002. In step 2, we test our model of the effect of vertical specialization on the technological competence base. For the model test we use a multiple regression analysis. In the multiple regression we analyze the effect of the changes in the values of our independent variables $V A_{x}, P D_{x}$ and $G D_{x}$ on the breadth of the technological competence base $T D_{x}$.

The data for all variables was collected on an annual basis. However, the data on $T D_{x}$ was summarized to four sub-periods (1983-1987, 1988-1992, 1993-1997, 19982002). In the ultimate model test, we study the causal effects for the entire time frame of the study ( $\left.\Delta_{1983-2002}\right)$. To use the entire time frame as relevant period of analysis is reasonable for at least two reasons: (1) With regard to the individual causal relationships between the explanatory variables and $T D_{x}$, it can be expected that there are considerable time lags (both, backward and forward lags, and with different scales across the industries), which can be captured in full effect only over the long time period; (2) the analysis of the long-term development(s) allows us to focus on structural changes only and to eliminate cyclical fluctuations.

The model which was introduced in section 2 consists of four hypotheses which aim to explain (the development of) the breadth of the technological competence base of our sample firms $\left(\Delta T D_{1983-2002}\right)$. The core bypothesis 1 specifies a negative, yet weak impact of vertical specialization (change in the value-add quota, $\Delta V A_{1983-2002}$ ) on the change in the technological competence base of firms $\Delta T D_{1983-2002}$. The strongest (positive) influence on the technological competence base describes bypothesis 2, which introduces the 'change in the degree of product diversification $\left(\Delta P D_{1983-2002}\right)$ ' as explanatory variable. Hypothesis 3 describes the influence of internationalization ('change in the degree of geographical diversification', $\Delta G D_{1983-2002}$ on the dependent variable $\Delta T D_{1983-2002}$. Finally, industry dummy variables $(A U, C H, E L, I T, M B, P H)$ test for the positive influence of the complexity of the firms' product portfolio on the breadth of the technological competence base, which was outlined in bypothesis 4 . The model also contains controlling variables. We control for the breadth of the firms' technology 
portfolio as well as the firms' value-add quotas at the beginning of the period of investigation (TD 1983 and $\left.V A_{1983}\right)$.

The formal model on the effect of vertical specialization on the technological competence base of firms is then defined as follows (including the constant $\beta_{\mathrm{o}}$ ):

$$
\begin{aligned}
& \Delta T D_{1983-2002}=\beta_{1} \Delta V A_{1983-2002}+\beta_{2} \Delta P D_{1983-2002}+\beta_{3} \Delta G D_{1983-2002}+\beta_{4 \mathrm{a}} A U+ \\
& \beta_{4 \mathrm{~b}} C H+\beta_{4 \mathrm{c}} E L+\beta_{4 \mathrm{~d}} I T+\beta_{4 \mathrm{e}} M B+\beta_{4 \mathrm{f}} P H+\beta_{5 \mathrm{a}} T D_{1983}+\beta_{5 \mathrm{~b}} V A_{1983}+\beta_{\mathrm{o}}
\end{aligned}
$$

Taking into consideration that the main variables are measured on a logarithmic scale, a linear relationship between the dependent and explanatory variables seems plausible. The model test is therefore based on a multiple linear regression analysis. Furthermore, we decided to use a hierarchical regression model. Due to their differing effects, not all of the independent variables are introduced concurrently into the model. The analysis occurs in four steps. First, the explanatory variable $\triangle P D_{1983-2002}$ with the strongest effect, which was outlined in hypothesis 2 , will be included into the model. In step two, the other discrete variables $\left(\Delta V A_{1983-2002}\right.$ and $\left.\Delta G D_{1983-2002}\right)$ with moderate impacts are incorporated. In the third step, the six industry dummy variables for technological complexity of the product portfolio will be included. Actually, technological complexity is an explanatory variable and as such a core part of our theoretical framework. However, due to the categorical approach in measuring complexity we treat the industry dummies like controlling variables. In the last step, two controlling variables $T D_{1983}$ and $W T_{1983}$ are included into the model.

For the last step, when all variables are included, the hierarchical regression analysis offers results that are identical to ordinary regression models, which incorporate all variables simultaneously. The advantage offered by the hierarchical approach is transparency on the individual effect sizes. Step-by-step introduction of the variables allows to determine dependencies in the estimations of the individual effect sizes and to control for the effects of other variables. Furthermore, the use of a hierarchical approach is advisable because of the incorporation of dummy-variables in the model.

\section{Results of the empirical study}

In section 4.1 we present the descriptive statistics of our study and give an overview of how our core variables have developed over the past 20 years (1983-2002). In the subsequent section 4.2 we then present the empirical results of the multiple regression analysis. These results provide the basis for confirming or rejecting our model hypotheses dealing with the research question, whether outsourcing of production will result in the outsourcing of technological resources and competencies, or not.

\subsection{Descriptive statistics}

How did the breadth of the technological competence base of the 50 sample firms evolve over the 20 years period of investigation? To what extent have the firms relied on outsourcing of production to external suppliers? The subsequent descriptive statistics in Figure 1 present evidence about the main dependent and explanatory variables. For each variable, figure 1 includes the descriptive statistics for the starting year of the study (1983), the end point (2002) and for the change in the variable values over the entire time frame $\left(\Delta_{1983-2002}\right)$. 
Figure 1: Descriptive statistics

\begin{tabular}{c|c|c|c|c|c}
\hline & $\mathbf{N}$ & Minimum & Maximum & Mean & Standard Deviation \\
\hline $\mathrm{TD}_{83}$ & 50 & 0.60 & 1.25 & 1.01 & 0.17 \\
\hline $\mathrm{TD}_{02}$ & 50 & 0.26 & 1.25 & 0.97 & 0.22 \\
\hline$\Delta \mathrm{TD}_{1983-2002}$ & 50 & -78.45 & 29.58 & -0.04 & 18.97 \\
\hline $\mathrm{VA}_{83}$ & 50 & 0.24 & 0.55 & 0.38 & 0.07 \\
\hline $\mathrm{VA}_{02}$ & 50 & 0.19 & 0.58 & 0.33 & 0.09 \\
\hline$\Delta \mathrm{AA}_{1983-2002}$ & 50 & -45.58 & 28.01 & -0.13 & 18.39 \\
\hline $\mathrm{PD}_{83}$ & 50 & 0.11 & 5.00 & 0.72 & 0.68 \\
\hline $\mathrm{PD}_{02}$ & 50 & 0.05 & 5.39 & 0.67 & 0.75 \\
\hline$\Delta \mathrm{PD}_{1983-2002}$ & 50 & -88.65 & 88.66 & -0.07 & 34.11 \\
\hline $\mathrm{GD}_{83}$ & 50 & 0.27 & 0.73 & 0.51 & 0.11 \\
\hline $\mathrm{GD}_{02}$ & 50 & 0.30 & 0.76 & 0.59 & 0.10 \\
\hline$\Delta \mathrm{GD}_{1983-2002}$ & 50 & -19.96 & 121.09 & 0.16 & 25.46 \\
\hline
\end{tabular}

The survey and analysis of our dependent variable reveals that the degree of technological diversification $\left(\Delta \mathrm{TD}_{1983-2002}\right)$ has decreased slightly by 4 percent on sample average. The value-add quota decreased by 13 percent, from 0.38 in 1983 to 0.33 in the year 2002. Obviously, the firms have engaged intensively in the outsourcing of production activities to external suppliers. The firms have also increasingly narrowed the spectrum of their product portfolios (-7 percent), while the degree of internationalization has been expanded considerably (+16 percent). Figure 2 shows the Pearson's correlation results for the discrete model variables (ex dummy variables).

Figure 2: Pearson's correlation results for the model variables $(\mathrm{N}=50)$

\begin{tabular}{|c|c|c|c|c|c|c|c|}
\hline & & (1) & (2) & (3) & (4) & (5) & (6) \\
\hline \multirow[t]{3}{*}{$\mathrm{TD}_{83}$} & Pearson Correlation & - & & & & & \\
\hline & Significance level (2-tailed) & & & & & & \\
\hline & $\mathrm{N}$ & 50 & & & & & \\
\hline \multirow[t]{3}{*}{$\Delta \mathrm{TD}_{1983-2002}$} & Pearson Correlation & -0.191 & - & & & & \\
\hline & Significance level (2-tailed) & 0.183 & & & & & \\
\hline & $\mathrm{N}$ & 50 & 50 & & & & \\
\hline \multirow[t]{3}{*}{$\mathrm{VA}_{83}$} & Pearson Correlation & $-0.371^{* *}$ & -0.133 & - & & & \\
\hline & Significance level (2-tailed) & 0.008 & 0.356 & & & & \\
\hline & $\mathrm{N}$ & 50 & 50 & 50 & & & \\
\hline \multirow[t]{3}{*}{$\Delta \mathrm{VA}_{1983-2002}$} & Pearson Correlation & $-0.318^{*}$ & 0.205 & 0.022 & - & & \\
\hline & Significance level (2-tailed) & 0.024 & 0.154 & 0.879 & & & \\
\hline & $\mathrm{N}$ & 50 & 50 & 50 & 50 & & \\
\hline \multirow[t]{3}{*}{$\Delta \mathrm{PD}_{1983-2002}$} & Pearson Correlation & 0.217 & $0.383^{* *}$ & -0.278 & -0.179 & - & \\
\hline & Significance level (2-tailed) & 0.131 & 0.006 & 0.051 & 0.212 & & \\
\hline & $\mathrm{N}$ & 50 & 50 & 50 & 50 & 50 & \\
\hline \multirow[t]{3}{*}{$\Delta \mathrm{GD}_{1983-2002}$} & Pearson Correlation & 0.270 & 0.061 & -0.020 & -0.190 & 0.257 & - \\
\hline & Significance level (2-tailed) & 0.058 & 0.676 & 0.892 & 0.185 & 0.072 & \\
\hline & $\mathrm{N}$ & 50 & 50 & 50 & 50 & 50 & 50 \\
\hline
\end{tabular}

**: Correlation is significant at the 0.01 level (2-tailed).

*: Correlation is significant at the 0.05 level (2-tailed). 


\subsection{Multiple regression}

The multiple regression analysis produces estimates for the coefficients of the independent variables as well as for the constant $\beta_{\mathrm{o}}$. The hierarchical regression analysis entails four steps. In the analysis we applied a significance level of 0.05. In total, the entire sample of firms $(\mathrm{N}=50)$ could be included; all firm data sets were complete.

The model summary in Figure 3 gives an overview of the influence of the independent variables on the change in the breadth of the technological competence base of firms following the four steps of the model. The coefficient of determination $\mathrm{R}^{2}$ and the value for the adjusted coefficient of determination (adjusted $\mathrm{R}^{2}$ ) continually increase by each model step. The values in the fourth step of the model, after inclusion of all relevant variables, are 0.401 and 0.247 for $\mathrm{R}^{2}$ and adjusted $\mathrm{R}^{2}$ respectively. These values reveal a strong causal relationship between the independent and the dependent variables in the complete model. Accordingly, 25 percent of the variation of the changes in the breadth of the technological competence base in the sample can be explained with use of the model. With a probability of error (Prob $>$ F) of 0.016, the complete model (model 4) shows significance.

Figure 3: Model summary of the hierarchical regression analysis of the determinants of the breadth of the technological competence base of firms

\begin{tabular}{|c|c|c|c|c|c|c|c|c|c|}
\hline \multicolumn{10}{|c|}{ Model Summary } \\
\hline \multirow[b]{2}{*}{ Model } & \multirow[b]{2}{*}{$\mathbf{R}$} & \multirow[b]{2}{*}{ R-Squared } & \multirow[b]{2}{*}{$\begin{array}{l}\text { Adjusted } \\
\text { R- } \\
\text { Squared }\end{array}$} & \multirow[b]{2}{*}{$\begin{array}{l}\text { Standard } \\
\text { Error }\end{array}$} & \multicolumn{5}{|c|}{ Change Statistics } \\
\hline & & & & & $\begin{array}{l}\text { Changes } \\
\text { in R- } \\
\text { Squared }\end{array}$ & $\begin{array}{l}\text { Changes } \\
\text { in } \mathrm{F}\end{array}$ & df1 & df2 & $\begin{array}{l}\text { Changes in } \\
\text { Signifi- } \\
\text { cance of } F\end{array}$ \\
\hline 1 & 0.383 & 0.146 & 0.129 & 17.708 & 0.146 & 8.232 & 1 & 48 & 0.006 \\
\hline 2 & 0.473 & 0.224 & 0.173 & 17.251 & 0.077 & 2.291 & 2 & 46 & 0.113 \\
\hline 3 & 0.580 & 0.336 & 0.207 & 16.898 & 0.112 & 1.388 & 5 & 41 & 0.249 \\
\hline 4 & 0.633 & 0.401 & 0.247 & 16.458 & 0.064 & 2.110 & 2 & 39 & 0.135 \\
\hline \multicolumn{10}{|c|}{ ANOVA } \\
\hline Model & & $\begin{array}{l}\text { Total Sum } \\
\text { of Squares }\end{array}$ & Df & $\begin{array}{c}\text { Mean } \\
\text { Squares }\end{array}$ & $F$ & $\begin{array}{l}\text { Signifi- } \\
\text { cance }\end{array}$ & & & \\
\hline \multirow[t]{3}{*}{1} & Regression & $2,581.465$ & 1 & $2,581.464$ & 8.232 & 0.006 & & & \\
\hline & Residuals & $15,052.477$ & 48 & 313.593 & & & & & \\
\hline & Total & $17,633.941$ & 49 & & & & & & \\
\hline \multirow[t]{3}{*}{2} & Regression & $3,944.791$ & 3 & $1,314.930$ & 4.419 & 0.008 & & & \\
\hline & Residuals & $13,689.151$ & 46 & 297.590 & & & & & \\
\hline & Total & $17,633.941$ & 49 & & & & & & \\
\hline \multirow[t]{3}{*}{3} & Regression & $5,926.91$ & 8 & 740.864 & 2.595 & 0.022 & & & \\
\hline & Residuals & $11,707.031$ & 41 & 285.537 & & & & & \\
\hline & Total & $17,633.941$ & 49 & & & & & & \\
\hline \multirow[t]{3}{*}{4} & Regression & $7,070.164$ & 10 & 707.016 & 2.231 & 0.016 & & & \\
\hline & Residuals & $10,563.777$ & 39 & 270.866 & & & & & \\
\hline & Total & $17,633.941$ & 49 & & & & & & \\
\hline
\end{tabular}


In the first step, the change in product diversification $\left(\triangle P D_{1983-2002}\right)$ is included into the model as the first independent variable. Across all four steps of the model, this variable has the strongest influence with a positive beta-value between 0.383 and 0.433 and the highest significance level (between 0.003 und 0.008) (see figure 4). In step 2, the variables $\Delta V A_{1983-2002}$ and $\Delta G D_{1983-2002}$ are added. At first, the value-add quota $\left(\Delta V A_{1983-2002}\right)$ shows a significant and positive value $(0,283)$. In the following steps 3 and 4 , however, the effect of the variable turns to an insignificant level. The effect of internationalization $\left(\Delta G D_{1983-2002}\right)$ appears to be insignificant in all relevant model steps (2-4). With the addition of the dummy variables in step 3 and the controlling variables in step 4, only the variables $I T$ und $T D_{1983}$ show significant regression coefficient values, in addition to $\triangle P D_{1983-2002}$. All other variables are not included in the final model due to insignificant (beta) coefficient values.

Figure 4: Variable coefficients differentiated by the four model steps

\begin{tabular}{|c|c|c|c|c|c|c|}
\hline & \multirow[t]{2}{*}{ Model } & \multicolumn{2}{|c|}{$\begin{array}{l}\text { Non-standardized } \\
\text { Coefficients }\end{array}$} & \multirow{2}{*}{$\begin{array}{c}\text { Coefficients } \\
\text { Beta }\end{array}$} & \multirow[t]{2}{*}{$T$} & \multirow{2}{*}{$\begin{array}{l}\text { Level of } \\
\text { Significance }\end{array}$} \\
\hline & & B & Standard error & & & \\
\hline \multirow[t]{2}{*}{1} & $\beta_{0}$ & -1.469 & 2.563 & & -0.573 & 0.569 \\
\hline & $\triangle P D_{1983-2002}$ & 0.213 & 0.074 & 0.383 & 2.869 & 0.006 \\
\hline \multirow[t]{4}{*}{2} & $\beta_{0}$ & 3.083 & 3.757 & & 0.821 & 0.416 \\
\hline & $\triangle P D_{1983-2002}$ & 0.241 & 0.075 & 0.433 & 3.187 & 0.003 \\
\hline & $\Delta G D_{1983-2002}$ & 0.002 & 0.101 & 0.003 & 0.024 & 0.981 \\
\hline & $\Delta V A_{1983-2002}$ & 0.292 & 0.138 & 0.283 & 2.119 & 0.040 \\
\hline \multirow[t]{9}{*}{3} & $\beta_{0}$ & 11.522 & 8.338 & & 1.382 & 0.174 \\
\hline & $\triangle P D_{1983-2002}$ & 0.233 & 0.079 & 0.420 & 2.952 & 0.005 \\
\hline & $\Delta G D_{1983-2002}$ & -0.030 & 0.108 & -0.040 & -0.275 & 0.785 \\
\hline & $\Delta V A_{1983-2002}$ & 0.261 & 0.204 & 0.253 & 1.279 & 0.208 \\
\hline & $\mathrm{CH}$ & -10.115 & 9.709 & -0.223 & -1.042 & 0.304 \\
\hline & $E L$ & -12.911 & 8.276 & -0.264 & -1.560 & 0.126 \\
\hline & IT & -17.776 & 8.373 & -0.347 & -2.123 & 0.040 \\
\hline & $M B$ & 1.874 & 10.917 & 0.027 & 0.172 & 0.865 \\
\hline & $P H$ & -5.993 & 10.647 & -0.123 & -0.563 & 0.577 \\
\hline \multirow[t]{11}{*}{4} & $\beta_{0}$ & 61.096 & 27.338 & & 2.235 & 0.031 \\
\hline & $\triangle P D_{1983-2002}$ & 0.22 & 0.078 & 0.396 & 2.812 & 0.008 \\
\hline & $\Delta G D_{1983-2002}$ & 0.006 & 0.107 & 0.008 & 0.054 & 0.957 \\
\hline & $\Delta V A_{1983-2002}$ & 0.180 & 0.231 & 0.175 & 0.781 & 0.44 \\
\hline & $\mathrm{CH}$ & -10.166 & 10.286 & -0.224 & -0.988 & 0.329 \\
\hline & $E L$ & -12.365 & 8.765 & -0.253 & -1.411 & 0.166 \\
\hline & IT & -21.652 & 8.388 & -0.423 & -2.581 & 0.014 \\
\hline & $M B$ & -2.638 & 11.280 & -0.038 & -0.234 & 0.816 \\
\hline & $P H$ & -10.391 & 14.587 & -0.213 & -0.712 & 0.480 \\
\hline & $T D_{1983}$ & -35.753 & 17.735 & -0.325 & -2.016 & 0.050 \\
\hline & $V A_{1983}$ & -36.303 & 52.393 & -0.128 & -0.693 & 0.492 \\
\hline
\end{tabular}

The strongest influence on the technological competence profile of the firms is exerted by changes in the breadth of the product portfolio. In the fourth step of the 
model, $\triangle P D_{1983-2002}$ has a significant and positive influence on the breadth of the technological competence base with a beta of 0.396. A negative influence, on the other hand, is exhibited by the IT-industry dummy IT as well as by the controlling variable $T D_{1983}$ (breadth of the technology base at the outset of the study). The latter result indicates that firms which commanded a rather broad technology spectrum at the beginning were more likely to refocus their technology portfolio than firms with more specialized technology profiles. In the comprehensive model (step 4), the constant variable $\beta_{\mathrm{o}}$ also takes on a significant value. No effect on the technological competence base of the firms is shown by the core explanatory variable $\Delta V A_{1983-2002}$ : With a beta-coefficient of 0.175 and a significance-level of 0.440 the value-add quota is not incorporated into the model. An even higher insignificance-level with a value of 0.957 exhibits the degree of internationalization ( $\Delta G D_{1983-2002)}$.

\section{Discussion of the results and implications of the study}

Our study focuses on the effects of vertical specialization on the breadth of the technological competence base of firms. Does the outsourcing of production and other value-adding activities result in the outsourcing of the corresponding technological activities? The descriptive empirical analysis provides a first answer to this question: Over the 20-year period (1983-2002) the development of the breadth of the technological competence base of the firms has been decoupled from the value-add quota. While the degree of vertical integration decreased by 13 percent, the degree of technological diversification only decreased by 2 percent across the time frame of the study.

In the empirical test of our theoretical model we analyzed the effect of vertical specialization in combination with other determinants on the breadth of the technological competence base of firms. The strongest and most significant effect on the technology portfolio of firms was caused by changes in the firms' product portfolio. The results of the regression analysis provide full support for bypothesis 2. On average, the sample firms have refocused their product portfolio significantly over the last twenty years: the average degree of product diversification in the sample decreased by seven percent. This decrease also had a negative effect on the breadth of the technology portfolio. With a beta-coefficient of 0.396 the effect was highly significant (0.008). The theoretical arguments behind hypothesis 2 are supported by the empirical results: The divestment of (non-core) product businesses goes hand in hand with the divestment of the underlying technological competence base.

In contrast, the outsourcing of production and other value-adding activities to external suppliers had no significant influence on the breadth of the technology profile of the firms. ${ }^{3}$ On average, the degree of vertical integration decreased considerably by 13 percent, but the technology portfolio remained unaffected by these changes. $H y$ pothesis 1 predicted a negative, yet weak, causal relationship between both variables. Although the empirical results reject our core bypothesis 1, the basic rationale behind the

3 In model step 2 a positive and significant effect of the changes in the value-add quota on the degree of technological diversification of the firms is shown. However, after the introduction of the industry dummy variables in step 3 the significant effect vanishes completely. 
theoretical framework (and the true intention of the hypothesis) is heavily supported: The line of argumentation developed out of the RBV framework, namely based on the 'absorptive capacity' view and the 'dynamic capabilities' concept, predicts that in technology-intensive industries an increase in outsourcing (vertical specialization) will not lead to a full reduction of the breadth and depth of the technological competence base. In order to stay innovative in the long run, firms must retain at least some technological competencies also in those areas of activities that have been outsourced. The empirical results indicate an even more "conservative" technology strategy of the sample firms: Firms that engage in outsourcing keep their technological competencies in-house.

The negative influence of the industry dummy variable $I T$ (with a beta of -0.423) can be explained with branch-specific developments in the industry's "architecture". Firms in the IT-industry have not only reduced their value-add quota considerably over the period of investigation, but they have also radically refocused and streamlined their product portfolios. The process of divesting non-core business activities in the IT industry coincided in most firms with a new product focus: Since the 1990's, IT firms have diversified to a great extent into services, especially into software and IT services (Burr/Stephan 2007). However, in the present study patents are used as a proxy for the technological competencies of the firms. This creates a serious deficiency for all (IT-)firms with a (new) product focus in services: At the European Patent Office most service technologies (service innovations) cannot be protected by patents (Burr et al. 2007). The negative effect of IT can therefore be explained by a lower patenting propensity of the firms.

According to the empirical results of the study no significant effect exists between geographical diversification and the breadth of the technological competence base of the firms. Evidently, hypothesis 3, which predicts a positive, although moderate causal relationship between the two variables, is rejected. This result can at least partly be explained by the way the variable 'degree of internationalization' was operationalized in the study. In our approach to measure internationalization we explicitly focused on foreign sales activities, i. e. market-driven internationalization. The results indicate that firms who expand their sales to new foreign markets most likely choose those markets in which they are able to sell their products with minimal (technological) changes. Consequently, internationalization which is primarily market-driven does not lead per se to an expansion of a firm's technological competence base. It was not part of the present study to determine the effects of internationalization of production or R\&D activities on the technological competence portfolio of firms. In cases, in which internationalization is measured by internationalization of production or R\&D, a positive effect might be expected (WIR 2005).

The technological complexity of the firms' product portfolio was operationalized by industry dummies. Of the six categorical variables only IT had a significant and negative impact on the dependent variable. As discussed above, this result should be interpreted with caution. In the IT industry, the negative effect on the technological competence portfolio is not necessarily linked to a "loss" of technological complexity in the main product offerings. Instead, the effect can be more likely explained by a shift into business areas like software and IT-related services, which are characterized 
by a lower patenting propensity of the firms (Blind et. al 2005). All other industry dummy variables had no significant effect on the technology portfolio of the firms. It is apparent that the technological complexity of the product offerings across industries has evolved along similar trajectories and thus has not forced the firms from different industries to expand their technology portfolios at faster or slower paces.

Finally, a number of critical remarks must be made about the present study and the interpretation of its empirical results. In the study, we analyzed the effects of the outsourcing of production on the breadth of the technological competence base of firms. However, in the analysis we have not distinguished between firms that operate primarily as systems integrators (so called Original Equipment Manufacturers, OEMs) or as suppliers in their respective industries. Although all firms in our sample are large multinational corporations, some of them do also have significant stakes in the supplier business (e. g., Bosch as a large automotive supplier firm). In this context it must be noted, however, that large supplier firms (so called tier-one suppliers) in turn also engage in the outsourcing of production to smaller component and parts suppliers (known as $2^{\text {nd }}$ - and $3^{\text {rd }}$-tier suppliers). The limited or even non-existing effect of the outsourcing of production on the technological competence base of the firms, which has been specified in our model, should thus not be confined to OEMs. As long as firms - OEMs as well as suppliers - in technology-intensive industries plan to stay innovative in the long run, outsourcing will not result in the outsourcing of technological competencies. However, this distinction between OEMs and suppliers should be taken into account in a separate hypothesis dealing with the firms" "role" in the value chain (OEMs versus suppliers) in follow-up studies.

Another facet that should be considered in follow-up studies is the mode of outsourcing. It probably makes a difference if firms in the course of outsourcing spin off parts of their business (including the employees) to external partners or if they simply delegate activities to externals on a contractual basis and keep the corresponding (human) resources in-house. In the spin-off case, outsourcing will probably more likely go along with the outsourcing of technological competencies due to the nonreplicability of the spun-off resources in question.

The current period of investigation covers 20 years from 1983 to 2002 . From the perspective of general strategic management this covers quite a long-term planning period. However, from the perspective of strategic management of technology, the 20 years period could still be too short: Establishing long lasting and successful partnerships with external suppliers that are really based on trust, might require more than 20 years. This holds especially true for industries with long lasting technology life-cycles, like pharmaceuticals or biotechnology, in which the development of new technologies can take up to 15 years or more. Irrespective of the longevity of the technology lifecycle, though, the creation of a trustful relationship between the outsourcing firm and its suppliers might require a considerable amount of time that goes far beyond the time-frame of the present study. Especially the creation of a common and shared innovation culture together with external suppliers, which not only simplifies coordination but also serves as the basic pillar of trust in the partnerships, will probably take time. Only when such an innovation culture and trustful partnerships have become manifest, firms might be willing not only to outsource production but also the under- 
lying technological knowledge. Thus, in upcoming studies on the outsourcing behavior of firms the time frame should be extended.

\section{References}

Andersen, B. H./Cantwell, J. (1999): How firms differ in their types of technological competencies and why it matters. CRIC Discussion Paper 25, January.

Baldwin, C. Y./Clark, K. B. (2000): Design rules: The power of modularity. Cambridge, MA: MIT Press.

Bengtsson, L./Dabhilkar, M. (2008): Manufacturing outsourcing and its effect on plant performance. In: Journal of Evolutionary Economics, 19(2): 231-257.

Blind, K./Edler, J./Friedewald, M. (2005): Software Patents - Economic Impacts and Policy Imlications. Cheltenham: Edward Elgar.

Bruisoni, S./Prencipe, A./Pavitt, K. (2001): Knowledge specialization, organizational coupling, and the boundaries of the firm: Why do firms know more than they make? In: Administrative Science Quarterly, 46: 597-621.

Bruisoni, S./Prencipe, A. (2001): Unpacking the black box of modularity: Technologies, products, organizations. In: Industrial and Corporate Change, 10: 179-205.

Buehner, R. (1991): Produktdiversifikation auf der Basis eigenen technologischen Know-hows. In: Zeitschrift für Betriebswirtschaft, 61(12): 1395-1412.

Burr, W./Stephan, M./Soppe, B./Weisheit, S. (2007): Patentmanagement, Stuttgart: Schäffer-Poeschel.

Burr, W./Stephan, M. (2007): Wertschöpfungsstrategien in einer schrumpfenden Industrie: Das Beispiel der Glasfasernetzausrüsterbranche. In: Schmalenbachs Zeitschrift für betriebswirtschaftliche Forschung, 59(5): 646-672.

Burr, W./Stephan, M. (2004): Arbeits- und Kompetenzverteilung in systemisch geprägten Industrien: Theoretische Überlegungen und empirische Befunde aus der Netzwerkausrüsterbranche. In: Hinterhuber, H. et al. (Hrsg.): Entwicklungen im Strategischen Kompetenzmanagement, Wiesbaden.

Busse v. Colbe, W./Chmielewicz, K. (1988): Das neue Bilanzrichtlinien-Gesetz. In: Die Betriebswirtschaft, 46: 289-347.

Cantwell, J./Piscitello, L. (1999): The Emergence of Corporate International Networks for the Accumulation of Dispersed Technological Competences. In: Management International Review, Special Issue 1999/1: 123-147.

Cantwell, J./Piscitello, L. (1997): A note on the Causality between Technological Diversification and Internationalization, Discussion Paper in Quantitative Economics and Computing 52, May, University of Reading, Department of Economics.

Carlsson, B./Stankiewicz, R. (1991): On the nature, function, and composition of technical systems. In: Journal of Evolutionary Economics, 1: 93-118.

Carmines, E. G./Zeller, R. A. (1979): Reliability and Validity Assessment, Sage University Paper series on Quantitative Applications in the Social Sciences, Newbury Park.

Cesaroni, F. (2004): Technological diversification, technology strategies and licensing in the chemical processing industry. In: Cantwell, J./Gambardella, A./Granstrand, O. (eds.): The Economics and Management of Technological Diversification, London.

Chandler, A. D. (1990): Scale and scope: The dynamics of industrial capitalism, Cambridge: Belknap Press.

Chesbrough, H. W./Teece, D. J. (1996): When is virtual virtuous? Organizing for innovation. In: Harvard Business Review: 65-73.

Christensen, J. F. (1998): Pursuing Corporate Coherence in Decentralized Governance Structures - The Role of Technology Management in Multi-Product Companies, DRUID Summer Conference 'Competencies, Governance and Entrepreneurship', June, Bornholm, Denmark.

Cohen, W. M./Levinthal, D. A. (1990): Absorptive Capacity: A New Perspective on Learning and Innovation. In: Administrative Science Quarterly, 35: 128-152.

Department of Trade and Industry (DTI, 2004): The Value Added Scoreboard 2004: The top 800 UK \& 600 European companies by value added, London 2004. 
Department for Business Innovation \& Skills (DBIS, 2009): The Value Added Scoreboard 2009: The top 800 UK \& 750 European companies by value added, London.

Eisenhardt, K./Martin, J. A. (2000): Dynamic Capabilities: What Are They. In: Strategic Management Journal, 21(7): 1105-1121.

Ethiraj, S./Puranam, P. (2004): The Distribution of R\&D effort in Systemic Industries: Implications for Competitive Performance. In: Baum, J. A. C./McGahan, A. M. (eds.): Business Strategy over the Industry Life Cycle, Boston (MA): 225-253.

Fai, F. M./Cantwell, J. (1999): The Changing Nature of Corporate Technological Diversification and the Importance of Organizational Capability. In: Dow, S. C./Earl, P. E. (eds.): Contingency, Complexity and the Theory of the Firm, Essays in Honour of Brian Loasby, Cheltenham.

Freiling, J. (2004): A Competence-based theory of the firm. In: management revue, 14(1): 27-52.

Gambardella, A./Torrisi, S. (1998): Does Technological Convergence Imply Convergence in Markets? Evidence from the Electronics Industry. In: Research Policy, 27: 445-463.

Gavetti, G. (1994): Strategies of Multinational Firms in the Patent Domain in Europe, Working Paper for the Commission of the European Communities, Milan.

Gerybadze, A./Stephan, M. (2007): Wachstumsstrategien und Marktkapitalisierung: Der unterschiedliche Einfluss von Internationalisierung und Produktdiversifikation auf den Unternehmenserfolg. In: Glaum, M./Hommel, U. (Hrsg.): Internationalisierung und Unternehmenserfolg, Schriften der Schmalenbachgesellschaft für Betriebswirtschaftslehre, Köln.

Granstrand, O./Oskarsson, Ch. (1994): Technology Diversification in "MUL-TECH" Corporations. In: IEEE Transactions on Engineering Management, 41(4): 355-364.

Granstrand, O./Sjölander, S. (1990): Managing Innovation in Multi-Technology Corporations. In: Research Policy, 19(1): 35-60.

Haller, A. (1997): Wertschöpfungsrechnung: Ein Instrument zur Steigerung der Aussagefähigkeit von Unternehmensabschlüssen im internationalen Kontext, Stuttgart.

Hitt, M. A./Hoskisson, R. E./Kim, H. (1997): International Diversification: Effects on Innovation and Firm Performance in Product-Diversified Firms. In: Academy of Management Journal, 40(4): 767798.

Jacquemin, A. P., Berry, C. H. (1979): Entropy measure of diversification and corporate growth. In: Journal of Industrial Economics, 27: 359-369.

Jensen, M./Meckling, W. (1976): Theory of the firm: Managerial behavior, agency costs andownership structure. In: Journal of Financial Economics, 3: 260-305.

Jolly, V. K. (1997): Commercializing New Technologies: Getting from Mind to Market, Harvard Business School Press, Boston (MA).

Langlois, R. N. (2003): The vanishing hand: The changing dynamics of industrial capitalism. In: Industrial and Corporate Change, 12(2): 351-385.

Langlois, R. N. (2000): Capabilities and vertical disintegration in process technology: The case of semiconductor fabrication equipment. In: Foss, N. J./Robertson, P. L. (eds.): Resources, Technology, and Strategy: Explorations in the Resource-Based Perspective, London: Routledge Press.

Leiblein, M. J./Reuer, J. J./Dalsace, F. (2002): Do make or buy decisions matter? The influence of organizational governance on technological performance. In: Strategic Management Journal, 23: 817-833.

Macher, J. T./Mowery, D. C. (2004): Vertical Specialization and Industry Structure in High Technology Industries. In: Baum, J. A. C./McGahan, A. M. (eds.): Business Strategy over the Industry Life Cycle, Amsterdam: 317-355.

Macher, J. T. (2003): Firm organization and performance in knowledge assets: An empirical examination in semiconductor manufacturing. Georgetown University Working Paper: 1-38.

Markides, C. C. (1996): Diversification, Refocusing and Economic Performance. Cambridge: Cambridge University Press.

Markides, C. C./Williamson, P. J. (1994): Related diversification, core competences and corporate performance. In: Strategic Management Journal, 15 (Special Issue, Summer): 149-165.

Metcalfe, S. J. (1998): Evolutionary Economics and Creative Destruction: The Graz Schumpeter Lectures 1, London. 
Narin, F./Carpenter, M. P./Woolf, P. (1984): Technological Performance Assessments Based on Patents and Patent Citation. In: IEEE Transactions on Engineering Management, EM-31(4): 172-183.

Palepu, K. K. (1985): Diversification Strategy, profit performance, and the entropy measure. In: Strategic Management Journal, 6: 223-255.

Patel P./Pavitt, K. L. (1997): The technological competencies of the world's largest firms: complex and path-dependent, but not much variety. In: Research Policy, 26: 141-156.

Pavitt, K. L. (1988): Uses and Abuses of Patent Statistics. In: Raan, A. F. J. van (eds.): Handbook of Quantitative Studies of Science and Technology, Amsterdam: 509-536.

Penrose, E. (1959): The Theory of the Growth of the Firm, Oxford: Oxford University Press.

Pettigrew, A./Whipp R. (1993): Managing the Twin Processes of Competition and Change: The Role of Intangible Assets, Oxford: Oxford University Press.

Pfaffmann, E. (2001): Kompetenzbasiertes Management in der Produktentwicklung, Wiesbaden.

Prencipe, A. (2000): Breadth and depth of technological capabilities in CoPS: The case of the aircraft engine control system. In: Research Policy, 29: 895-911.

Prencipe, A. (1997): Technological capabilities and product evolutionary dynamics: A case study from the aero engine industry. In: Research Policy, 25: 1261-1276.

Rothaermel, F. T./Hitt, M. A./Jobe, L. A. (2006): Balancing vertical integration and strategic outsourcing: Effects on product portfolio, product success, and firm performance. In: Strategic Management Journal, 27: 033-1056.

Rugman, A. (2008): The Regional Multinationals, MNEs and "Global" Strategic Management, Cambridge: Cambridge University Press.

Sahal, D. (1981): Alternative conceptions of technology. In: Research Policy, 10(1): 2-24.

Sanchez, R./Mahoney, J. T. (1996): Modularity, flexibility, and knowledge management in product and organization design. In: Strategic Management Journal, 17: 63-76.

Schmoch, U. (1999): Impact of international patent applications on patent indicators. In: Research Evaluation, 8(August): 119-131.

Stephan, M./Pfaffmann, E./Sanchez, R. (2008): Modularity in cooperative product development: the case of the MCC 'smart' car. In: International Journal of Technology Management, 13(September): 99111.

Stephan, M. (2003): Determinanten der technologischen Diversifikation, Wiesbaden: DUV Verlag.

Stephan, M./Pfaffmann, E. (2001): Detecting the Pitfalls of Foreign Direct Investment: Scope and Limits of FDI Data. In: Management International Review, 41(2): 189-218.

Stigler, G. (1951): The division of labor is limited by the extent of the market. In: The Journal of Political Economy, 59(3): 185-193.

Stuart, T. E./Podolny, J. M. (1996): Local Search and the Evolution of Technological Capabilities. In: Strategic Management Journal, 17(1): 21-38.

Teece, D./Pisano, G./Shuen, A. (1997): Dynamic Capabilities and Strategic Management. In: Strategic Management Journal, 18(7): 509-533.

Tunzelmann, von N. G. (1998): Localised technological search and multitechnology companies. In: Economics of Innovation and New Technology, 6:231-255.

United Nations Conference on Trade and Development (UNCTAD, 2008): World Investment Report 2008: Transnational Corporations and the Infrastructure Challenge, Geneva: UN Press.

United Nations Conference on Trade and Development (UNCTAD, 2005): World Investment Report 2005: The internationalization of R\&D, Geneva: UN Press.

United Nations Conference on Trade and Development (UNCTAD, 1998): World Investment Report 1998: Trends and Determinants, Geneva: UN Press.

Weber, H. K. (1994): Die Wertschöpfungsrechnung auf der Grundlage des Jahresabschlusses. In: Wysocki, K. von/Osterloh, J. (eds.): Handbuch des Jahresabschlusses in Einzeldarstellung, Loseblatt, Köln.

Zollo, M./Winter, S. G. (2002): Deliberate Learning and the Evolution of Dynamic Capabilities. In: Organization Science, 13(3): 339-351. 